$12-2010$

\title{
Searching for the Right Way to Begin Class
}

John D. Lawry

Fordham University, lawry@fordham.edu

Follow this and additional works at: https://fordham.bepress.com/psych_facultypubs

Part of the Educational Methods Commons, and the Psychology Commons

\section{Recommended Citation}

Lawry, J. D. (2010). Searching for the right way to begin class. About Campus, 15(5).

This Article is brought to you for free and open access by the Psychology at DigitalResearch@Fordham. It has been accepted for inclusion in Psychology Faculty Publications by an authorized administrator of DigitalResearch@Fordham. For more information, please contact considine@fordham.edu. 
Word Count: 1250 (including cover page)

\title{
Searching for the Right Way to Begin Class
}

\author{
John D. Lawry, Ph.D. \\ 281 Crest Drive \\ Tarrytown, NY 10591-4329 \\ 914-631-1323 \\ lawry@fordham.edu
}

John D. Lawry is Professor Emeritus of psychology at the former Marymount College of Fordham University, Tarrytown, New York. He is the editor of College 101: A First Year Reader (McGraw-Hill, 1999) and author of May You Never Stop Dancing: A Professor's Letters to his Daughter (St. Mary's Press, 1998) and Guide to the History of Psychology (University Press of America, 1991).

Submitted to Editor Deb McCarthy, Campus commons 


\section{Searching for the Right Way to Begin Class}

When I accepted my first college teaching position I never really gave much thought to how a class should begin. I expected that I would call the role and begin just like my former professors had done in grad school. However, in 1965, when I first came to Marymount, a Catholic Women's College in Tarrytown, NY, I noted that according to the faculty handbook, the faculty was asked to begin class with a prayer to the Holy Spirit ("Come, Holy Spirit, fill the hearts of thy faithful and enkindle in them the Fire of Thy Love. ..") with the students standing and facing a prominent crucifix on the wall. If not comfortable doing so, the faculty was instructed to invite a student to lead the prayer. I had no issue with this practice, however, since I had spent my undergraduate years in a Roman Catholic seminary studying for the priesthood. By 1968, as a result of attempting to qualify for New York State aid via the recently legislated "Bundy" Aid Program (named after George McBundy who headed the commission) to independent colleges and universities, there was a rush to de-Catholicize the classroom. The crucifixes came down from the front of the classroom and the prayer to the Holy Spirit was eliminated. (Most Catholic students today do not even know the prayer.) Marymount was one of the first church-related colleges to qualify and received aid the following year in 1969.

For many years thereafter I struggled to fill the vacuum left by the elimination of prayer to begin class and searched for a replacement. While visiting the yoga ashram, Kripalu, in Lenox, MA, a former Jesuit seminary named Shadowbrook, I discovered that the yoga classes there began and ended with the chanting of "OM," and was followed by the Sanskrit greeting by the instructor, "Jai Bhagwan," which roughly translates into "I honor the Divine within you," to which the students repeated the greeting. Struck by the atmosphere created by such an opening ritual, I decided to experiment with the ritual in my psychology classes at Marymount. I even went so far as to purchase a "Cosmic OM tuning fork," to 
get the right pitch for the OM. A music major commented that it was a $D$ and I read somewhere that $D$ is the sound of the universe. The practice of chanting OM was a huge success and many students commented favorably in their final papers about the calming effect of the ritual.

This is what Nahoko, a Japanese-American student, wrote about her experience of chanting OM:

One of the most attractive qualities that made me and all the students comfortable was the famous OM at the beginning of the class. This simple sound of OM not only was a pleasing start, but it was also the strong, magical word that brought the entire class into a unity. For me, in addition to the harmonious quality, it was a moment of experiencing a spiritual atmosphere, where I was always reminded to think about or say a prayer for someone in my mind by creating a bridge from my heart to the loving God. Through the repetitive, ritual OM at the beginning of each class, the whole class melted from a solid sugar into a blended, sweet liquid solvent, in which everyone could be open and interact with one another by sharing one's own experiences as well as her opinions.

I used this ritual for almost twenty years until one student questioned why we were using a nonChristian ritual in a Catholic college. I replied that it was a good question and that I would consult with the college Chaplain, Fr. John B. Breslin, S.J., who was appointed as a result of the recent merger of Marymount with Fordham, a Jesuit University, in 2002. Fr. Breslin informed me that he did not have any issue with such a ritual in a Catholic college, and in fact, he believed that exposing students to a variety of religious practices was a good thing. Nevertheless, I began to worry whether the practice might make other students uncomfortable. I decided to replace the ritual with a minute or two of silence. I told the 
class that it was up to each student to utilize the silence. They could pray, meditate, daydream, etc. The only requirement being that they respected the silence by being quiet and still.

What I discovered was quite extraordinary. Students appreciated the silence. I wasn't sure how they would respond to something so foreign in their busy lives. In fact, one student shared that it was the only silence in her day and that she needed it and really appreciated it. Another student, Christine, began her final paper this way:

First and foremost, before I write anything I'm going to take a moment and close my eyes and sit in silence. It's amazing what the power of a moment can do, sitting in silence for a minute or two stops the world from spinning, stops the lights from flashing, brings a sense of calmness and allows the focus to be directed specifically on the task at hand. Taking a moment of silence is like taking a deep breath that allows one to be re-centered and brings things into their right context. At the beginning of each class, the moment of silence felt as though it brought the class together in peace rather than in chaos and tension.

Another student, Michele, used the time to pray as she reported in her first journal entry for the class: "It is especially refreshing to have a minute of silence before we begin each class. It is a wonderful and unique opportunity for me to pray openly at the start of each class. I feel very blessed for this and to have a professor that allows this in his classroom."

What I recognize now is that how my classes begin is important. The students' comments suggest that the ritual of silence and time for reflection does make a difference. It wasn't until the Bundy Aid Program forced the issue at my college that I paid attention to this aspect of teaching. Not having a 
ritual that separates the beginning of class, (a "sacred space"?), from the busyness of life is a mistake. But not just anything will do. Having a minute or two of silence may not work at many institutions, especially those in the public sector where silence is frequently construed as prayer. Every teacher has to find their own ritual and asking the students would be a good place to start. "How have you begun classes in your previous educational experience? What has worked and what hasn't? Would anyone like to volunteer to begin the class with a ritual of their own choice?" I must admit that I never thought to ask these questions. Next semester I will do exactly that! 